\title{
Tinker, Tailor, Policy-maker ... ... ... The Wider Context of Prosecution Service Work
}

\author{
Marianne Wade • Bruno Aubusson de Cavarlay • \\ Josef Zila
}

Published online: 1 August 2008

(C) Springer Science + Business Media B.V. 2008

\begin{abstract}
This article explores the wider ambit of prosecutorial work outside classic criminal proceedings in 11 European criminal justice systems. It provides an overview of the roles a prosecutor is expected to play, e.g. whether a contribution to national or local crime prevention policy or to act in victim's interest is expected. It further provides detail as to the setting within which prosecutors work, describing in how far they are politically accountable and/or subject to orders in their daily work.
\end{abstract}

Keywords Institutions of crime prevention · Prosecutor's wider role $\cdot$ Prosecutorial accountability and independence

Above all this study regards the prosecution service as part of an institutional chain which makes up the criminal justice system (see also Wade 2006). Jehle et al. 2008 and Peters et al. 2008 have shown it to be a part of the chain which can prevent further parts becoming involved (by ending cases) or can decisively influence how other institutions further down the chain deal with cases, by providing for them to be treated via alternative proceedings. Even where the legally "normal" path is taken, we see the PPS influencing court work on cases in various ways (see Wade et al. 2008b). The PPS position in the chain also enables it

M. Wade $(\bowtie)$

Max Planck Institute for Foreign and International Criminal Law, Günterstalstr. 73, 79100 Freiburg i.B., Germany

e-mail:m.wade@mpicc.de

B. A. de Cavarlay

Center for Sociological Research on Law and Penal Institutions (CESDIP), Ministère de Justice/CNRS, 43 Boulevard Vauban, F-78280 Guyancourt (Paris), France

e-mail: aubusson@ext.jussieu.fr

J. Zila

Faculty of Law, Stockholm University, 10691 Stockholm, Sweden

e-mail: Josef.Zila@juridicum.su.se 
Table 1 PPS general role within criminal justice system

\begin{tabular}{|c|c|c|c|c|c|c|c|c|c|c|c|}
\hline & $\mathrm{CH}^{1}$ & $\mathrm{D}$ & $\mathrm{E}$ & EW & $\mathrm{F}$ & $\mathrm{H}$ & HR & $\mathrm{NL}$ & PL & $\mathrm{S}$ & TR \\
\hline PPS is an objective body & $\mathrm{X}$ & $\mathrm{X}$ & & $\mathrm{X}$ & $\mathrm{X}$ & $\mathrm{X}$ & $\mathrm{X}$ & $\mathrm{X}$ & $X^{2}$ & $\mathrm{X}$ & $X$ \\
\hline $\begin{array}{l}\text { PPS obliged to ensure all aspects of a case are } \\
\text { investigated }\end{array}$ & $X$ & $\mathrm{X}$ & & & $\mathrm{X}$ & $X$ & $\mathrm{X}^{3}$ & $X$ & $X$ & $X$ & $X$ \\
\hline $\begin{array}{l}\text { PPS obliged to ensure court receives all relevant } \\
\text { information }\end{array}$ & $X$ & $X$ & & & $X^{4}$ & $X$ & $X$ & $X^{5}$ & $X$ & X & $\mathrm{X}$ \\
\hline $\begin{array}{l}\text { PPS obliged to provide accused/defence with all } \\
\text { relevant information }\end{array}$ & $X$ & $X^{6}$ & & $X^{7}$ & $X^{8}$ & $X^{9}$ & $\mathrm{X}^{10}$ & $X^{11}$ & $X$ & $\mathrm{X}$ & $\mathrm{X}$ \\
\hline
\end{tabular}

1 Strong role in all procedural stages.

2 At court level PPS has an adversarial role.

3 EM conducts the investigation upon the request of the authorised prosecutor.

4 Only during main proceedings.

5 Not during the investigative stage.

6 No active cooperation required. PPS simply has to allow defence access to case file.

7 In the stage preparing for court (charge lodged); regulated by guidelines set out by the CPS.

8 Only during main proceedings.

9 The defence has right to have all information. During the investigation only when it is allowed by the Code of Criminal Procedure (taking into consideration the interest of the investigation). After the conclusion of investigation the suspect and the defence counsel shall be enabled to inspect all documents - with the exception of those treated confidentially - that may serve as the basis for charges.

${ }^{10}$ No active cooperation required. PPS simply has to allow defence access to case file.

11 The defence has the right to have all information (also during investigative stage), provided it does not obstruct the investigation. Some documents may always be examined by the defence (such as notes of testimonies of the suspect himself). After the investigation (or if no investigation took place, after the notification of no prosecution or the writ of summons) all documents are available to the defence.

to be a control instance in relation to the investigative stage, although it is increasingly unable to fulfil this role alongside its other responsibilities (see Elsner et al. 2008).

This role in relation to the courts during full proceedings suggests and is indeed indicative of a wider role prescribed to the PPS.

As Table 1 shows in the traditionally inquisitorial continental European criminal justice systems, the PPS obligations to the court in full proceedings are reflective of the wider role ascribed to it; namely as an objective body with obligations to ensure a case is fully, adequately and objectively investigated as well as to provide the defence with the information required to be able to argue against the prosecution case in court. The English and Welsh prosecution service's status as objective and its evidential obligations show that this role is one also being taken on by the PPS there, i.e. there is convergence with the continental systems. The lack of obligations in controlling the police and assisting the courts there are possibly more indicative of the high degree of independence enjoyed by those organs and possibly the relative novelty of having a PPS. Some developments relating to the PPS/police relationship (e.g. the altered responsibility for charging) might, however, be taken as indicative of potential for change in this respect.

Table 2 shows the PPS role as being wider than that of a prosecution institution in the stricter sense in that it shows the PPS to have duties beyond dealing with individual cases in order to see that a specific offence is correctly investigated and adequately reacted to. In more than half of the jurisdictions studied, the PPS is under a duty to contribute to local and (or) national crime policy and to play a role in preventing crime. European prosecution 
Table 2 PPS' wider role

\begin{tabular}{|c|c|c|c|c|c|c|c|c|c|c|c|}
\hline PPS also active as/in & $\mathrm{CH}$ & $\mathrm{D}$ & $\mathrm{E}$ & EW & $\mathrm{F}$ & $\mathrm{H}$ & HR & NL & PL & $\mathrm{S}$ & TR \\
\hline National Crime Policy & & & & $\mathrm{X}$ & $\mathrm{X}$ & & $\mathrm{X}$ & $\mathrm{X}$ & $\mathrm{X}$ & $\mathrm{X}$ & \\
\hline Local crime policy & & $\mathrm{X}$ & & $\mathrm{X}$ & $\mathrm{X}$ & & $\mathrm{X}$ & $\mathrm{X}$ & $\mathrm{X}$ & $\mathrm{X}$ & \\
\hline Crime prevention & & & & $\mathrm{X}$ & $\mathrm{X}$ & $\mathrm{X}$ & $\mathrm{X}$ & $\mathrm{X}$ & $\mathrm{X}$ & $\mathrm{X}$ & \\
\hline Victims' interests & & $\mathrm{X}$ & & $\mathrm{X}$ & $\mathrm{X}$ & $\mathrm{X}$ & $\mathrm{X}$ & $\mathrm{X}$ & $\mathrm{X}$ & $\mathrm{X}$ & $\mathrm{X}$ \\
\hline Victims' compensation claim & & & & & & $\mathrm{X}$ & & $\mathrm{X}$ & $\mathrm{X}$ & $\mathrm{X}$ & \\
\hline Compensating victim where offender unknown & & & & & $\mathrm{X}$ & & & & & & \\
\hline Ordering execution of sentence & & $\mathrm{X}$ & & & $\mathrm{X}$ & & & $\mathrm{X}$ & & & $\mathrm{X}$ \\
\hline Ensuring fines paid & & & & & $\mathrm{X}$ & & & $\mathrm{X}$ & & & $\mathrm{X}$ \\
\hline Ensuring prison sentence served & & $\mathrm{X}$ & & & $\mathrm{X}$ & & & $\mathrm{X}$ & & & $\mathrm{X}$ \\
\hline Can prosecute administrative offences & & $\mathrm{X}$ & & & & & $\mathrm{X}$ & $\mathrm{X}$ & & & $\mathrm{X}$ \\
\hline Civil cases if this is in the public interest & & & & & $\mathrm{X}$ & $\mathrm{X}$ & $\mathrm{X}^{1}$ & $\mathrm{X}$ & $\mathrm{X}$ & & $\mathrm{X}$ \\
\hline Recovery of assets through civil courts & & & & & & & $\mathrm{X}^{2}$ & & $\mathrm{X}^{3}$ & & \\
\hline
\end{tabular}

1 Represents Republic of Croatia, ministries and other governmental bodies.

2 Only the assets of the Republic of Croatia.

${ }^{3}$ Represents the treasury where its interests have been jeapordised.

services have a clear mandate to consider victim's interests and in some cases to take responsibility for their compensation (see Wade et al. 2008a, for a more detailed account of this issue).

More rarely the PPS has an administrative role in ensuring the sentences ordered by the CJS are in fact imposed, although often this work is in fact performed by a specialist section of the PPS.

In France, Hungary, Croatia, the Netherlands, Poland and Turkey there is further indication that the PPS is indeed regarded as the representative of the public interest, being charged also with undertaking civil proceedings where it is in the public interest to do so.

Taken together with PPS powers to deal with cases or influence how they are dealt with, as well as the influence it sometimes holds over police work (see, e.g. Table 5 in Elsner et al. 2008), there are significant arguments to support the idea of prosecution services as decisive criminal justice institutions in Europe; in some cases in the wider criminal policy context as well as in relation to the individual case, nitty-gritty of ensuring offenders are brought to justice.

The PPS in Croatia is neither associated with the judicative nor with the executive state power. It is an autonomous and independent, hierarchically structured, monochratic judicial body authorised and bound to act against perpetrators of criminal offenses and other punishable offenses, to undertake legal actions in order to protect the assets of the Republic of Croatia and to file legal remedies for the protection of the Constitution and the law. ${ }^{1}$ It also takes care of wider criminal policy and represents victims' interests. Thus the PPS is more than a mere law enforcement agency. The Chief Public prosecutor is obliged to submit once a year his or her report to Parliament and to the Ministry of Justice (see also Turković 2008).

The Crown Prosecution Service (CPS) in England and Wales is too new to have achieved any high profile and to most people it does not register as a separate organisation. Furthermore politicians still more naturally turn to the police to solve developing problems such as drugs or terrorism. It is relevant that, when the Ministry of Justice was created in

\footnotetext{
${ }^{1}$ Art. 124. par. 1 Constitution of the Republic of Croatia, art. 2. par. 1. Act on State Attorney's Office.
} 
mid-2007, there was no discussion whatsoever about whether the CPS should be included within it, and it remains a separate ministerial organisation, almost by default.

However, its centralised structure and strong web site give it a high profile amongst the law enforcement agencies and it is gradually taking more roles to itself. It takes a full part in local and national criminal justice decisions planning and decisions. Moreover it is gradually talking onto itself more and more roles previously carried out by others: eg charging, appearing in High Courts, previously carried out by private lawyers on CPS behalf, and as an experiment, interviewing rape victims (see also Lewis 2006).

The French prosecution service is considered part of the judiciary, viewed as the representative of the public interest and thus naturally endowed with powers and obligations to ensure only the guilty are subjected to the trials of process, let alone convicted. A duty to act in the public interest can also be seen in the wider context of prosecution service work with prosecutors playing an active role, particular at regional level, determining crime prevention policy. Their role in relation to victims; representing and compensating them where no one else can be required to, and indeed the right to intervene in procedures beyond the criminal justice arena where this is called for, indicates a particular role within and responsibility to society. With recent reforms strengthening prosecutor powers within criminal proceedings as they are taken away from the juge d'instruction, the question as to how many of these roles a prosecutor can comprehensively perform, becomes ever more pressing (see also Aubusson 2006).

The German prosecution service may have some influence upon crime policy on a local level because of involvement with local crime prevention boards but policy or prevention considerations are beyond its mandate which is restricted to a strong role ensuring investigations are performed correctly and cases dropped, disposed of or taken to court. In this role its mandate is fairly wide as the PPS can deal with administrative offences if it feels it would be opportune to do so, usually because the suspect is also a suspect in a criminal case. Special departments of the PPS are charged with ordering and, to a certain extent, ensuring execution of sentence (see also Elsner and Peters 2006).

The prosecutor acts as the public accuser in the Hungarian system of criminal procedure so s/he represents the public interest. The Prosecutor General - who is elected by Parliament for six years - shall answer to Parliament and shall provide a report of the activities of the PPS every year. In his reports he describes the trends in and statistical data relating to the activities of the PPS.

The PPS may have influence upon crime prevention by notifying the authority concerned about the circumstances which made the commitment of the given offence possible or easier.

The PPS has a strong role in the investigation: the prosecutor orders or performs an investigation to establish the conditions for accusation. When the investigating authority conducts an investigation or certain investigative actions independently, the prosecutor supervises compliance with the law throughout the procedure and ensures that the persons participating in the procedure - among others the defendant as well as the victim - can exercise their rights. Pre-trial disposals or bringing the case before court are decisions made by the public prosecutor.

Special departments of the county and central PPS offices are charged with controlling the execution of sentences (see also Roth 2008).

In the Netherlands the PPS is very powerful and also monopolistic in the sense that only the PPS can prosecute (or not). They have a large influence on criminal (crime prevention) policy, at a local as well as national level. This is done very effectively through their strong internal hierarchical structure headed by a board of Prosecutors - General. 
The PPS is part of the judiciary, which means that it is considered an objective representative of the public interest. Accordingly the prosecutor must (and does sometimes) ask for an acquittal if he thinks the evidence is not sufficient.

Although the PPS is also formally responsible for the execution of sentences, in practice this will be done by the Ministry of Justice (see also Blom and Smit 2006).

The law of 1985 on the Prokuratura stressed the role of the PPS as a guardian of the public interest in Poland. In practice it is the Minister of Justice - the Attorney General who undertakes steps concerning national crime policy both in the fields of legislative amendments and in giving general guidelines specifing how and when prosecutors are to use their powers. It is also possible, that the PPS plays a role at local level, but this does not happen often. As the guardian of public interest a prosecutor has to be objective, however in some situation the PPS must act to the benefit of the State Treasury. The role of the PPS in Poland - as an objective representative of public interest - is strengthened by a power to institute and/or join any civil and administrative proceedings - if it is required for the protection of law and order. This measure, although not used very often, is a very powerful tool that the State can use to influence all kinds of proceedings (see also Bulenda et al. 2006).

In the Spanish criminal justice system, the PPS has to exercise penal action and also, whenever the victim does not, civil action (i.e. a civil procedure in order to obtain compensation for the damage caused by the offence). It is interesting to point out that neither the organic statute of the PPS nor the Spanish Constitution include a clear inventory of the functions of the PPS. In fact, the different laws mentioning the PPS include mainly generic statements such as the one pointing out that the PPS is responsible for "satisfying social interests". In practice, although the PPS is an autonomous body belonging to the Judicial Power, there is a link with the Executive Power because the Government plays a major role in the appointment of the State's Public Prosecutor. The latter is one of the key players in the implementation of national criminal policy. This is done mainly through internal orders such as the one which, in 1989, required PPS staff to look for consensual solutions with the defence, thus encouraging the Spanish form of plea bargain (see also Aebi and Balcells 2008).

According to the law, the PPS in Sweden has, in principle, no other task than the prosecution of offences. There are, however, some exceptions. Firstly, the PPS fulfils certain tasks connected to the enforcement of sanctions. This is mainly in relation to situations in which a decision concerning the enforcement of sanctions are to be made by a court; only the PPS is in a position to bring the case to court. It must be pointed out that the PPS is not the authority that will supervise the enforcement of sanctions. This is the task of the Swedish Prison and Probation Service, or sometimes, as regards young offenders, the social services. These authorities hand the case over to the prosecutor. The PPS can further be active in some respect relating to the enforcement of fines and psychiatric care. The second area in which the PPS fulfil tasks not related to the prosecution of crimes is international co-operation. Thirdly, the PPS is an important actor in the development of criminal policy in general and at a local level. This task is not regulated by law, but a matter of fact. Finally, the PPS is empowered to make decisions on visiting bans in accordance with the Act on Visiting Bans (see also Zila 2006).

In Switzerland and Turkey the PPS role is restricted to prosecuting crimes and providing legal assistance (see Gilliéron and Killias 2008 and Hakeri 2008).

\section{Accountability and Uniformity}

Given this spectrum of responsibilities and powers it is not surprising that Europe's prosecution services are embedded in a particular institutional framework. In this context a 
particularly interesting aspect of PPS status comes to mind. On the one hand, as an organ implementing policy, certainly bound by the European principle that there should be equality before the law and that law should be applied equally (e.g. a drop or disposal only used in appropriate case and then across the board), it is clearly desirable that PPSs should be subject to a certain degree of control and indeed be democratically or politically accountable for their actions. On the other hand, as a body required to be objective, often with quasi-judicial powers or at least significant influence upon how individual cases are treated within the CJS, there is a strong argument for a need to minimise political influence upon decisions in individual cases to secure against corruption and undue influence. In other words PPSs should be accountable in implementing policy but politically independent.

Table 3 shows the efforts made by the countries studied to ensure these goals are meet. The variety of paths taken is perhaps indicative of the difficulty of finding the right balance. Not surprisingly all systems are provided for with a formal legal basis. In most cases the institutional set-up tends towards political independence with a strong internal hierarchy to ensure equal handling. Interestingly the Swiss, French and Turkish systems opt for strong political influence upon the service via the Ministry of Justice. In the other study countries

Table 3 PPS' status and accountability

\begin{tabular}{|c|c|c|c|c|c|c|c|c|c|c|c|}
\hline & $\mathrm{CH}$ & $\mathrm{D}$ & $\mathrm{E}$ & EW & $\mathrm{F}$ & $\mathrm{H}$ & HR & NL & PL & $\mathrm{S}$ & TR \\
\hline PPS has a formal legal basis & $\mathrm{X}$ & $\mathrm{X}$ & $\mathrm{X}$ & $\mathrm{X}$ & $\mathrm{X}$ & $\mathrm{X}$ & $\mathrm{X}$ & $\mathrm{X}$ & $\mathrm{X}$ & $X$ & $\mathrm{X}$ \\
\hline $\begin{array}{l}\text { PPS is a politically independent institution with strong } \\
\text { internal hierarchical binding }\end{array}$ & & $\mathrm{X}$ & $\mathrm{X}$ & $\mathrm{X}^{1}$ & & $\mathrm{X}$ & $\mathrm{X}$ & $\mathrm{X}$ & $\mathrm{X}$ & $\mathrm{X}$ & $\mathrm{X}$ \\
\hline $\begin{array}{l}\text { PPS is a externally strongly tied institution with strong } \\
\text { internal hierarchical binding }\end{array}$ & $X^{2}$ & 3 & & $\mathrm{X}^{4}$ & $\mathrm{X}$ & & 5 & & & & $X$ \\
\hline PPS is bound by ministerial instruction & $\mathrm{X}$ & $\mathrm{X}$ & $X^{6}$ & & $\mathrm{X}$ & & & $\mathrm{X}$ & & & $\mathrm{X}$ \\
\hline PPS is bound by written external national guidelines & & $\mathrm{X}$ & & $\mathrm{X}$ & & & & $\mathrm{X}$ & & & $\mathrm{X}$ \\
\hline PPS is bound by written internal national guidelines & & & $\mathrm{X}$ & $\mathrm{X}$ & & $\mathrm{X}$ & $\mathrm{X}$ & $\mathrm{X}$ & $\mathrm{X}$ & $\mathrm{X}$ & $\mathrm{X}$ \\
\hline PPS is bound by regional political guidelines & & $\mathrm{X}$ & & & & & & & & & \\
\hline $\begin{array}{l}\text { PPS is answerable to external complaints institution } \\
\text { PPS is answerable to Parliament }\end{array}$ & 8 & & $X^{7}$ & X & & $\mathrm{X}^{9}$ & $\mathrm{X}^{10}$ & & & & \\
\hline
\end{tabular}

${ }^{1}$ The PPS is an institution somewhere between these two options. It is too early to say where it will end up. It is quite a weak institution within the CJS, but it could develop its powers over the next 10-20 years. The ministry cannot issue general instructions (guidelines) to the PPS.

2 Minister of Justice can give a case-specific order to prosecute.

3 Theoretically true, less so in practice although Ministries of Justice do provide a significant amount of guidelines to guide practice in general.

4 The PPS is an institution somewhere between these two options. It is too early to say where it will end up. It is quite a weak institution within the CJS, but it could develop its powers over the next 10-20 years. The ministry cannot issue general instructions (guidelines) to the PPS.

5 The State Attorney General submits a consolidated activity report of the PPS to the Croatian Parliament and Government at least once a year.

${ }^{6}$ Not bound by government by general or specific instructions but depends on Ministry of Justice, the latter determines the policy to be followed by PPS.

7 Ombudsman.

${ }^{8}$ Not to the parliament but to the government.

9 Prosecutor General is answerable to Parliament.

10 The State Attorney General submits a consolidated activity report of the PPS to the Croatian Parliament and Government at least once a year. 
Table 4 Individual PP can be given orders by

\begin{tabular}{|c|c|c|c|c|c|c|c|c|c|c|c|}
\hline & $\mathrm{CH}$ & $\mathrm{D}$ & $\mathrm{E}$ & EW & $\mathrm{F}$ & $\mathrm{H}$ & HR & $\mathrm{NL}$ & PL & $\mathrm{S}$ & $\mathrm{TR}^{1}$ \\
\hline \multicolumn{12}{|l|}{ Government } \\
\hline Ministry of Justice or Equivalent & $\mathrm{X}$ & & & & $X^{2}$ & & & $\mathrm{X}^{3}$ & $\mathrm{X}$ & & \\
\hline Federal State Ministry ('Länder") & & $\mathrm{X}$ & & & & & & & & & \\
\hline Organisational head of service & $\mathrm{X}$ & $\mathrm{X}$ & & & $\mathrm{X}$ & $\mathrm{X}$ & $\mathrm{X}$ & $\mathrm{X}$ & $\mathrm{X}$ & $X^{4}$ & \\
\hline Regional PP management & & $\mathrm{X}$ & & $\mathrm{X}$ & $\mathrm{X}$ & $\mathrm{X}$ & & $\mathrm{X}$ & $\mathrm{X}$ & & \\
\hline Superior PP & $\mathrm{X}$ & $\mathrm{X}$ & & $\mathrm{X}$ & $\mathrm{X}$ & $X^{5}$ & $X^{6}$ & $\mathrm{X}$ & $\mathrm{X}$ & $X^{7}$ & $\mathrm{X}$ \\
\hline
\end{tabular}

1 Ministry of Justice regularly reviews file.

2 Ministry of Justice can deliver an instruction to prosecute a case or to request specific investigative acts. Such written instructions are included in the written file. No order to drop a case can be delivered by the Ministry of Justice.

3 Although in theory possible, this will hardly ever happen.

4 The orders may concern administrative matters, not processual legal actions. If the superior PP doesn't accept a decision of a subordinate PP, he/she may take over prosecution.

5 Regularly discusses cases with immediate superior.

6. Regularly discusses cases with immediate superior.

7 See fotnote 3 .

it cannot be claimed that there is no political influence, however, as more senior positions within the PPS are in contact with political structures.

A number of PPSs are directly subservient to ministerial instruction with the rest at least bound by guidelines either internal or external, upon which political structures exercise some influence. In Switzerland, Spain, England and Wales, Hungary and Croatia further political accountability is achieved by further external controlling institutions.

The desire for control despite political independence is demonstrated fairly clearly by Table 4.

All the systems examined provide for a superior to be able to order an individual PP to act differently and the majority of study countries allow the head of service (this is the Ministry of Justice, e.g. in France, the Netherlands and Poland) to do the same. In this way internal hierarchy can be used to ensure equal treatment or that policy is implemented correctly. Only four jurisdictions allow direct intervention by the responsible ministry and those systems have often developed mechanisms to reconcile this with other interests (e.g. France: la plume est servee mais la parolee est libre).

Although the PPS is an independent judicial body it is responsible to the Croatian Parliament and the State Attorney General submits a consolidated activity report of the PPS to the Croatian Parliament and Government at least once a year. By accepting the report the Croatian Parliament confirms that the PPS has fulfilled its obligations for the past year. The Prosecutors' Assembly considers issues concerning the activities of the prosecutor's offices and prosecutors' service and makes proposals for the resolution thereof. The Minister of Justice may at any time ask a chief public prosecutor to provide information on the current state of cases the PPS is engaged in, if such information is needed to fulfil objectives of the Ministry. Everyone has the right to file a complaint against delays in performance of duties of the PPS or misbehavior of public prosecutors and other employees of the PPS. The PPS is independent in making decisions in individual cases, but it is responsible for performing its tasks efficiently and with the due respect for human rights.

Because of the newness of the CPS in England and Wales and, as mentioned above, there is little public discussion about CPS accountability versus independence. There is 
some tension amongst the police in relation to the CPS increasing its powers: e.g. in the way the CPS tends to give more advice on the way investigations should be conducted and evidence gathered.

The status of French prosecutors is a matter of considerable controversy and has been the subject of intense debate in recent years. Whilst prosecutors are members of the judiciary and thus formally entitled to greater independence than those in other areas of state employment, the desire and need to ensure their political accountability - particularly considering the extent of their ability to enforce criminal policy via extensive discretionary powers - has ensured they have remained in a delicate position. They are subject to the hierarchy of the organisation and thus also to circulars by the Ministry of Justice which heads the service. As shown above, an individual prosecutor is also obliged by a direct order from the Ministry to bring a prosecution (an order to drop is not permitted) though the balance required is protected by the "la plume est servee mais la parole est libre" rule which means that a prosecutor can plead orally for acquittal whilst representing the prosecution as ordered.

Because the German prosecution service is regarded as a judicial organ performing executive functions and legal certainty is regarded as paramount, political accountability of the PPS is regarded as highly important there. For this reason, the PPS is marked by a strong internal hierarchy enforcing detailed guidelines issued by the Länder Ministries of Justice. Theoretically these can also give an individual PP orders how to act in a specific case but this really happens in practice. Any such order given must be recorded in writing in the relevant case file.

The strong internal hierarchy is a relevant feature of the PPS in Hungary. A superior has the right to order an individual PP how to act in a concrete case or - more typically - the Prosecutor General issues guidelines concerning different fields of activities (e.g. relating to the activity of the PP during an investigation, before the court, in juvenile cases etc.). In some cases the individual public prosecutor has the right to reject the order issued by the superior in a particular case (e.g. if the order is in contradiction with the law).

In relation to accountability it must be mentioned that procedural participants (generally the defendant, defence counsel and the victim) have a right to legal remedy in cases when the PP decides to drop or dispose of the case. In this way the court may make the final decision even if the PP did not originally want to bring the case before court.

The relationship between the PPS, the Minister of Justice and Parliament in the Netherlands is rather complicated. While a largely independent and powerful PPS is very effective, the Minister of Justice is politically accountable and must therefore have some influence on the PPS. In theory he has this influence, in prosecution policy in general as well as in individual cases. In practice, the influence is restricted to general prosecution policy through regular contacts between the Minister and the Board of Prosecutors General. If the Minister decides to give instructions (to prosecute or not to prosecute) in individual cases, he may only do that after consulting the Board of Prosecutors - General. Furthermore the instructions will be part of the case file. And an instruction by the Minister not to prosecute must be notified to Parliament. This type of instruction is hardly ever given in practice.

In Poland although an individual prosecutor cannot be given orders by a body situated outside of the PPS structure, it does not mean that the PPS is not politically accountable. The source of this situation is in the fact that it is the Minister of Justice who - ex lege exercises the function the head of service. The last two years have shown that the power of the Minister of Justice - the Attorney General over individual prosecutors can be overused and - in fact - there is no effective remedy that can be used by a prosecutor to reconcile a 
conflict between accountability and independence. (It suffices to say, that the PPS instituted preparatory proceedings against a prosecutor who - as a President of Association of Prosecutors of the Republic of Poland - prepared a protest against - inter alia - political involvement of the PPS. The protest did not refer to present situation but to proceedings which in fact had begun earlier).

Since the adoption of the Spanish constitution in 1978, the PPS (Ministerio Fiscal) is an autonomous organ that belongs to the judicial power even if it has no jurisdictional functions (only the courts have this function).

Since the Swiss PPS implements the state right to punish associated with the Executive, it is itself part of the Executive and appointed by it. As part of the Executive the PPS answers to the Government and the latter has the right to issue orders and to impose disciplinary measures to the former's members. As the Government only rarely makes use of its power to issue orders, the PPS is functionally autonomous and independent, i.e. in performing its tasks and in its decision making policies.

The PPS in Sweden is a central authority. According to the Swedish constitutional rules, neither the Government nor the Minister of Justice are allowed to give instructions to the Prosecutor General concerning prosecutions or the interpretation of law in individual cases, if the case concerns individuals (which is always the case in criminal law). The Minister of Justice is politically accountable for PPS policy. However, the only means the Government has at its disposal as far as the control of PPS activity is concerned, are laws, regulations and statements of a general nature. It is expected, that the prosecuting authorities follow the intentions of the Government's criminal policy. The PPS is a unified, nationwide and hierachical organisation. Within this hierarchy, the supervising prosecutor may control the activity of subordinated prosecutors or take over the prosecution in an individual case.

One cannot speak of a strong ministerial influence in the Turkish CJS. Even in practice influence from the Ministry is very, very rare. Previously the Minister of Justice could order the prosecution of a case, not, however, that one be dropped. He now has no power even to force prosecution. The only influence remaining is a requirement for charges to be pressed by the Minister for certain offences (in particular international criminal offences) in order for the PPS to be able to lodge an indictement. No one can issue an order to a prosecutor except a superior prosecutor.

\section{Conclusion}

Clearly European PPSs are institutions trusted with responsibilities beyond those of a prosecution of offences in the strict sense in some cases going to the point of representing the public interest. As such, developments giving them more power to decide how to deal with cases is fitting to the wider context, however, it renders issues of accountability and political independence a relatively thorny field in many of the study countries, of even greater urgency.

\section{References}

Aebi, M., \& Balcells, M. (2008). The prosecution service function within the Spanish Criminal Justice System. Heidelberg: Springer. European Journal on Criminal Policy and Research, 14(2-3), 311-331. Aubusson de Cavarlay, B. (2006). The prosecution service function within the French Criminal Justice System. In Jehle/Wade, Coping with overloaded criminal justice systems - The rise of prosecutorial power across Europe (pp 185-205). Heidelberg: Springer. 
Blom, M., \& Smit, P. (2006). The prosecution service function within the dutch criminal justice system. In Jehle/Wade, Coping with overloaded criminal justice systems - The rise of prosecutorial power across Europe (pp 237-256). Heidelberg: Springer.

Bulenda, T., Gruszczynska, B., Kremplewski, A., \& Sobota, P. (2006). The prosecution service function within the polish criminal justice system. In J. M. Jehle, \& M. Wade (Eds.), Coping with overloaded criminal justice systems (pp. 257-284). Heidelberg: Springer.

Elsner, B., \& Peters, J. (2006). The prosecution service function within the german criminal justice system. In Jehle/Wade, Coping with overloaded criminal justice systems - The rise of prosecutorial power across Europe (pp 207-236). Heidelberg: Springer.

Elsner, B., Lewis, C., \& Zila, J. (2008). Police prosecution service relationship within criminal investigation. European Journal on Criminal Policy and Research, 14(2-3), 203-224.

Gilliéron, G., \& Killias, M. (2008). The prosecution service function within the swiss criminal justice system. European Journal on Criminal Policy and Research, 14(2-3), 333-352.

Hakeri, H. (2008). The prosecution service function within the turkish criminal justice system. European Journal on Criminal Policy and Research, 14(2-3), 353-368.

Jehle, J. -M., Smit, P., \& Zila, J. (2008). The public prosecutor as the key player: Prosecutorial case-ending decisions. European Journal on Criminal Policy and Research, 14(2-3), 161-179.

Lewis, C. (2006). The prosecution service function within the english criminal justice system. In Jehle/Wade, Coping with overloaded criminal justice systems - The rise of prosecutorial power across Europe. Heidelberg: Springer, pp 151-184.

Peters, J., Aubusson de Cavarley, B., Lewis, C., \& Sobota, S. (2008). Negotiated case-ending settlements: Ways of speeding up the (court) process. European Journal on Criminal Policy and Research, 14(2-3), 145-159.

Roth, E. (2008). The prosecution service function within the hungarian criminal justice system. European Journal on Criminal Policy and Research, 14(2-3), 289-309.

Turković, K. (2008). The prosecution service function within the croatian criminal justice system. European Journal on Criminal Policy and Research, 14(2-3), 263-287.

Wade, M. (2006). The power to decide - Prosecutorial control, diversion and punishment in European criminal justice systems today. In Jehle/Wade, Coping with overloaded criminal justice systems, Heidelberg: Springer, p. 27-126.

Wade, M., Lewis, C., \& Aubusson de Cavarley, B. (2008a). Well-informed? Well represented? Well nigh powerless? Victims and prosecutorial decision-maiking. European Journal on Criminal Policy and Research, 14(2-3), 249-261.

Wade, M., Smit, P., \& Aubusson de Cavarley, B. (2008b). The prosecution role where courts decide cases. European Journal on Criminal Policy and Research, 14(2-3), 133-143.

Zila, J. (2006). The prosecution service function within the swedish criminal justice system. Heidelberg: Springer, pp 285-311. 